\title{
Facile Synthesis of $\mathrm{AgCl} / \mathrm{BiYO}_{3}$ Composite for Efficient Photodegradation of RO16 under UV and Visible Light Irradiation \\ (Sintesis Mudah Komposit $\mathrm{AgCl} / \mathrm{BiYO}_{3}$ untuk Fotodegradasi Cekap RO16 di bawah Sinaran UV dan Cahaya Boleh Lihat)
}

\author{
URAIWAN SIRIMAHACHAI*, HUSNA HAROME \& SUMPUN WONGNAWA
}

\begin{abstract}
$\mathrm{AgCl} / \mathrm{BiYO}{ }_{3}$ composite was successfully synthesized via the aqueous precipitation method followed by calcination. The varied amount of $\mathrm{AgCl}$ (10, 20 and 30\%) was mixed into $\mathrm{BiYO}_{3}$ via sonochemical-assisted method. The structures and morphologies of the as-prepared $\mathrm{AgCl} / \mathrm{BiYO}{ }_{3}$ composite were characterized by $x$-ray diffraction (XRD), scanning electron microscopy (SEM) and UV-vis diffused reflectance spectroscopy (UV-vis DRS). The optical absorption spectrum of AgCl/

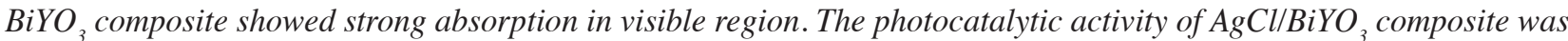
evaluated by the photodegradation of reactive orange16 (RO16), which was selected to represent the dye pollutants, under UV and visible light irradiation. The results indicated that $20 \% \mathrm{AgCl} / \mathrm{BiYO}{ }_{3}$ photocatalyst was the most capable photocatalyst in this series in the degradation of RO16 under both UV and visible light illumination within 1 h. Moreover, the mechanism of photocatalytic degradation of $\mathrm{AgCl} / \mathrm{BiYO} \mathrm{O}_{3}$ was elucidated using three types of free radical scavengers. The significant enhancement was attributed to the formation of $\mathrm{AgCl} / \mathrm{BiYO}$, heterojunction resulting in the low electronhole pair recombination rate.
\end{abstract}

Keywords: $\mathrm{BiYO}_{3}$; photocatalyst; visible light

\section{ABSTRAK}

Komposit $\mathrm{AgCl} / \mathrm{BiYO}_{3}$ telah berjaya disintesis melalui kaedah pemendakan akueus diikuti dengan pengkalsinan. Jumlah berbeza $\mathrm{AgCl}$ (10, 20 dan 30\%) dicampur ke dalam $\mathrm{BiYO}_{3}$ melalui kaedah sonokimia berbantu. Struktur dan morfologi disediakan sebagai komposit $\mathrm{AgCl}_{\mathrm{B} i Y \mathrm{O}_{3}}$ telah dicirikan oleh pembelauan sinar-x (XRD), microskopi elektron pengimbasan (SEM) dan spektroskopi UV-vis pantulan resapan (UV-vis DRS). Spektrum penyerapan optik komposit AgCl/ $\mathrm{BiYO}_{3}$ menunjukkan penyerapan yang kuat di kawasan boleh nampak. Aktivitifotomangkinan komposit AgCl/BiYO dinilai melalui fotodegradasi reaktif jinggal6 (RO16) yang telah dipilih bagi mewakili bahan cemar pewarna, di bawah UV dan penyinaran cahaya boleh nampak. Keputusan menunjukkan bahawa $20 \%$ fotomangkin AgCl/BiYO adalah fotomangkin paling efektif dalam siri ini dalam degradasi Rol6 di bawah kedua-dua UV dan penyinaran cahaya boleh nampak dalam tempoh 1 jam. Selain itu, mekanisme degradasi fotomangkinan AgCl/BiYO $\mathrm{O}_{3}$ telah diterangkan menggunakan tiga jenis pemangsa radikal bebas. Peningkatan ketara ini disebabkan oleh pembentukan hetero-simpang $\mathrm{AgCl}_{\mathrm{B}} \mathrm{BiY \textrm {O } _ { 3 }}$ yang mengakibatkan kadar penggabungan semula pasangan lohong elektron adalah rendah.

Kata kunci: $\mathrm{BiYO}_{3}$; cahaya boleh nampak; fotomangkin

\section{INTRODUCTION}

Heterogeneous photocatalytic oxidation has received overwhelming interest as a potential method in the degradation of environmental pollutant. It is a process in which a photoexcitable solid catalyst is illuminated by light with the energy greater than the band gap of the semiconductor and electron-hole pairs are generated within the semiconductor. If electron and hole do not recombine, each can migrate to the surface of the solid catalyst and participate in the degradation (oxidation and reduction) of pollutants (Chong et al. 2010; Tariq et al. 2007). Semiconductor photocatalyst can be modified to expand their photoresponse to the visible region for pollutant decomposition such as by doping with metal/nonmetal (Chen et al. 2010; Hu et al. 2010; Zhou et al. 2011) or coupling with other small band gap semiconductor to form composite photocatalyst (Cao et al. 2011).

In order to develop novel photocatalysts for solar photocatalytic degradation of pollutants such as organic dyes, the Bi-based photocatalyst is one of the very interesting materials (Cai et al. 2015; Cheng et al. 2015; $\mathrm{Xu}$ et al. 2014; Xu et al. 2014). The efficient sunlight active photocatalyst, $\alpha-\mathrm{Bi}_{2} \mathrm{O}_{3}$ nanorod, was synthesized and characterized which showed an excellent performance in the photocatalytic degradation of rhodamine $\mathrm{B}$ and 2,4,6-trichlorophenol (Kansal et al. 2015). However, another Bi-containing photocatalyst, $\mathrm{BiYO}_{3}$, which having the perovskite structure has not much been studied in the photocatalytic process because of its poor photocatalytic performance (Qin et al. 2009). Wu et al. 
(2015) synthesized a nanorod structure of $\mathrm{BiYO}_{3}$ under hydrothermal condition which could photocatalytic degrade $68.5 \%$ of tetracycline within $3 \mathrm{~h}$ under visible light irradiation. In another work, the effect of templates on the formation of $\mathrm{BiYO}_{3}$ nanostructure was studied and followed by their photocatalytic reduction of $\mathrm{CO}_{2}$ under visible-light irradiation (Qin et al. 2016). Until recently, the enhancement of photocatalytic activity of semiconductor has become a key strategy in the design of composites, therefore, it is interesting to develop the photocatalytic activity of $\mathrm{BiYO}_{3}$ by using the heterojunction system.

In this paper, $\mathrm{AgCl} / \mathrm{BiYO}_{3}$ composite, with different mole percents of $\mathrm{AgCl}$ fabricated onto $\mathrm{BiYO}_{3}$, were prepared with the aim for low cost of production and ease of synthesis. The morphology and optical property were characterized. In addition, the photocatalytic activity and mechanism of $\mathrm{AgCl} / \mathrm{BiYO}_{3}$ composite toward $\mathrm{RO} 16$ dye under UV and visible light irradiation were also investigated.

\section{MATERIALS AND METHODS}

Bismuth (III) nitrate $\left(\mathrm{Bi}\left(\mathrm{NO}_{3}\right)_{3}\right.$, Sigma-Aldrich), yttrium (III) nitrate $\left(\mathrm{Y}_{\left(\mathrm{NO}_{3}\right.}\right)_{3}$, Sigma-Aldrich), ammonia solution $\left(\mathrm{NH}_{3}\right.$, Labscan), silver (I) nitrate $\left(\mathrm{AgNO}_{3}, \mathrm{VWR}\right.$, Belgium) and potassium chloride ( $\mathrm{KCl}$, Merck) were used with no further purification. First, the $\mathrm{Bi}\left(\mathrm{NO}_{3}\right)_{3}$ solution was added dropwise to $\mathrm{Y}\left(\mathrm{NO}_{3}\right)_{3}$ solution with stirring. The mixture was adjusted to $\mathrm{pH}=8$ by using $0.5 \mathrm{M} \mathrm{NH}_{3}$ solution to yield a white precipitate. The precipitate was dried at $90^{\circ} \mathrm{C}$. The obtained powder was ground and calcined at $750^{\circ} \mathrm{C}$ for $3 \mathrm{~h}$ under normal atmosphere (Qin et al. 2009). The final product was yellow powders.

The ultrasound-assisted preparation of $\mathrm{AgCl} / \mathrm{BiYO}_{3}$ composite with various amounts of $\mathrm{AgCl}$ loading was as follows: the desired amount of the as-prepared $\mathrm{BiYO}_{3}$ and $\mathrm{KCl}$ were added to $50 \mathrm{~mL}$ of deionized water. The powders were mixed in a $100 \mathrm{~mL}$ glass beaker for $30 \mathrm{~min}$ and then sonicated for $30 \mathrm{~min}$. Subsequently, the desired amount of $\mathrm{AgNO}_{3}$ solution was rapidly injected to the mixture above. Finally, the mixture was further sonicated for $1 \mathrm{~h}$. The product was collected by washing with deionized water and dried at $80^{\circ} \mathrm{C}$ for $12 \mathrm{~h}$ (Xue et al. 2015). The products were assigned as 10, 20 and $30 \% \mathrm{AgCl} / \mathrm{BiYO}_{3}$.

The power X-ray diffraction (XRD) patterns of the samples were measured by X'Pert MPD diffractometer (Philips, Netherlands) using $\mathrm{CuK} \alpha(\lambda=0.154 \mathrm{~nm})$ at a scanning rate $(2 \theta)$ of $0.05^{\circ} \mathrm{s}^{-1}$ and a $2 \theta$ range of $5-90^{\circ}$ at $40 \mathrm{kV}$ and $30 \mathrm{~mA}$. The morphology of the prepared samples was analyzed using electron microscope (SEM, Quanta-400, FEI). UV-vis diffused reflectance spectra of the synthesized samples were determined by UV-2450 UV-Visible spectrophotometer.

The photocatalytic activity of $\mathrm{AgCl} / \mathrm{BiYO}_{3}$ was evaluated by the degradation of reactive orange 16 (RO16), a cationic dye, under UV and visible light. The UV and visible light sources were 3 bulbs of 18 Watt black light lamp (Sylvania, USA) and 3 bulbs of 18 Watt fluorescent lamp (Sylvania, USA), respectively. In a typical experiment, $150 \mathrm{~mL}$ of the reaction suspension containing $150 \mathrm{mg}$ catalyst and RO16 $\left(1 \times 10^{-5} \mathrm{M}\right)$ was placed in a tightly closed reaction chamber. Prior to illumination, the suspension was magnetically stirred in the dark for $30 \mathrm{~min}$ to establish an adsorption-desorption equilibrium between the photocatalyst and dye. Then it was illuminated for a certain period of time with constant stirring. About $5 \mathrm{~mL}$ of the suspension was collected at each specific irradiation time interval, centrifuged and the supernatant was collected to analyze the absorption spectrum using UV-2600 spectrophotometer (Shimadzu, Japan). The dye concentration was determined from the wavelength at maximum absorption, $494 \mathrm{~nm}$, with deionized water as a reference.

The set up of experiment with scavengers was similar to the photocatalytic degradation experiment above. A specified amount of scavengers was introduced into the RO16 solution prior to addition of the catalyst. The scavengers used in this experiment were: tert-butanol (TBA), ammonium oxalate (AO), and 1,4-benzoquinone (BQ).

\section{RESULTS AND DISCUSSION}

The XRD patterns of the as-synthesized $\mathrm{AgCl} / \mathrm{BiYO}_{3}$ with different $\mathrm{AgCl}$ content and $\mathrm{BiYO}_{3}$ are shown in Figure 1. All of diffraction peaks can be indexed to the cubic phase of $\mathrm{BiYO}_{3}$, which is in good agreement with the standard card (JCPDF No.00-055-0702) while AgCl (JCPDF No.01-0715209 ) is cubic structure. A noticeable increase in intensity of $\mathrm{AgCl}$ diffraction peaks $(2 \theta=27.8)$ was observed with increasing $\mathrm{AgCl}$ content in $\mathrm{AgCl} / \mathrm{BiYO}_{3}$, whereas that of $\mathrm{BiYO}_{3}(2 \theta=28.4)$ decreased simultaneously due to changing of relative abundances of $\mathrm{AgCl}$ and $\mathrm{BiYO}_{3}$ as $\mathrm{AgCl}$ was increased.

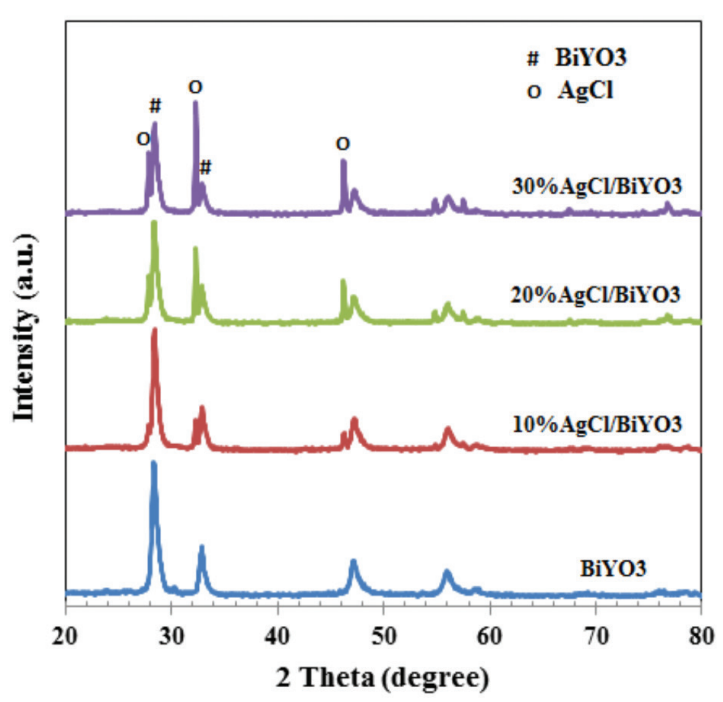

FIGURE 1. XRD patterns of $\mathrm{BiYO}_{3}, 10 \%, 20 \%$, and $30 \% \mathrm{AgCl} / \mathrm{BiYO}_{3}$ 
The UV-Vis diffused reflectance spectra (DRS) of the photocatalysts are displayed in Figure 2(a). It can be seen that $\mathrm{BiYO}_{3}$ and $\mathrm{AgCl} / \mathrm{BiYO}_{3}$ are responsive to visible light as both samples exhibit absorption in the visible light range $(\lambda>400 \mathrm{~nm})$. The absorption edge of $\mathrm{BiYO}_{3}$ appear at longer wavelength than that of $\mathrm{AgCl} / \mathrm{BiYO}_{3}$. This may come from the nature of $\mathrm{AgCl}$ which has its own absorption edge at $423 \mathrm{~nm}$ (Cao et al. 2011). Hence, the onset absorption of $\mathrm{AgCl} / \mathrm{BiYO}_{3}$ composite was blue shifted with the increasing of $\mathrm{AgCl}$ contents. The optical bandgap energy $\left(\mathrm{E}_{\mathrm{g}}\right)$ can be determined by using the Kubelka-Munk relation as shown in (1) (Pan et al. 2013; Yan et al. 2013);

$$
(\alpha h v)=\mathrm{A}\left(\mathrm{h} v-\mathrm{E}_{\mathrm{g}}\right)^{1 / 2},
$$

where $\alpha$ is the absorption coefficient; $\boldsymbol{v}$ is the radiation frequency; $\mathrm{h}$ is the Planck's constant; $\mathrm{A}$ is a constant; and $\mathrm{E}_{\mathrm{g}}$ is the band gap. The $\mathrm{E}_{\mathrm{g}}$ value can be obtained from Figure 2(b) by using the intersection point where the tangent of the curve intersects with the energy $(x)$ axis. All the $\mathrm{E}_{\mathrm{g}}$ values obtained by this method are listed in Table 1 .

The conduction band (CB) and valence band (VB) potentials can be calculated by the following empirical equations (Wang et al. 2008):
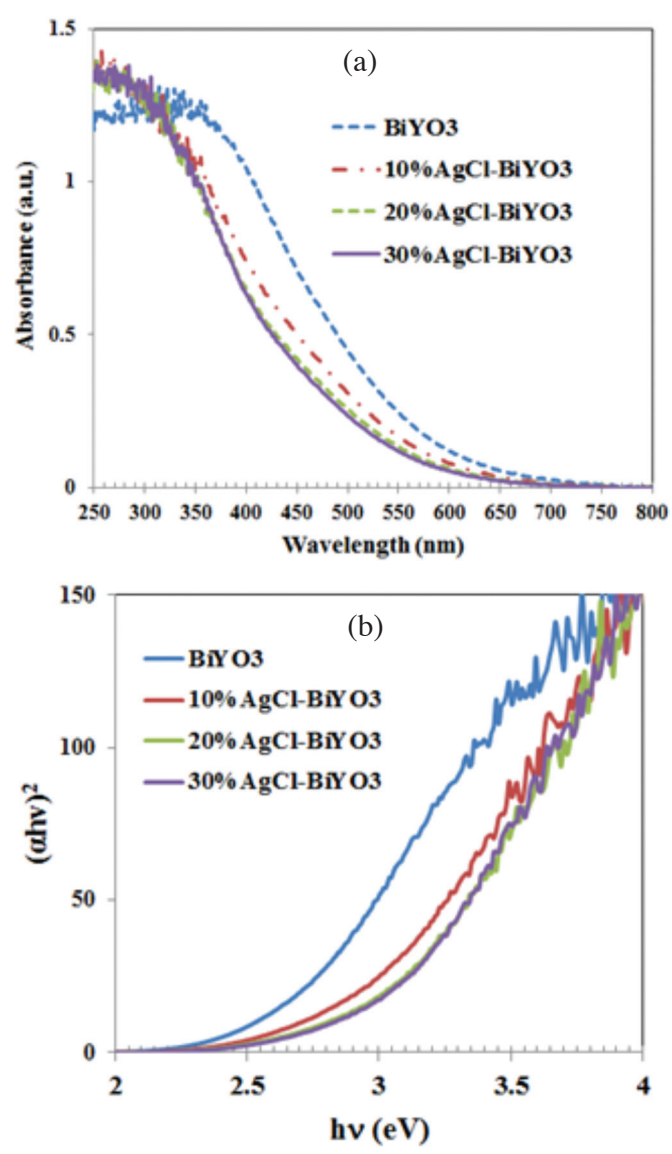

FIGURE 2. UV-Visible diffused reflectance spectra of the asprepared photocatalysts (a) and optical absorption of samples using the Kubelka-Munk equation (b)

$$
\begin{aligned}
& \mathrm{E}_{\mathrm{VB}}=\mathrm{X}-\mathrm{E}^{\mathrm{e}}+0.5 \mathrm{E}_{\mathrm{g}} \\
& \mathrm{E}_{\mathrm{CB}}=\mathrm{E}_{\mathrm{VB}}-\mathrm{E}_{\mathrm{g}}
\end{aligned}
$$

where $\mathrm{E}_{\mathrm{VB}}$ is the valence band edge potential; $\mathrm{E}_{\mathrm{CB}}$ is the conduction band edge potential; $\mathrm{X}$ is the electronegativity of the semiconductor (which is the geometric mean of the electronegativity of the constituent atoms); and $\mathrm{E}^{\mathrm{e}}$ is the energy of free electrons on the hydrogen scale $(\sim 4.5 \mathrm{eV})$. By using (2) and (3), the $\mathrm{E}_{\mathrm{CB}}$ and $\mathrm{E}_{\mathrm{VB}}$ of $\mathrm{BiYO}_{3}$ were calculated to be -0.04 and $2.58 \mathrm{eV}$, respectively. These values together with the $\mathrm{E}_{\mathrm{CB}}$ and $\mathrm{E}_{\mathrm{VB}}$ of $\mathrm{AgCl}(0.11$ and $3.04 \mathrm{eV}$ ) (Cao et al. 2011) will be used to determine the photocatalytic mechanism diagram in this work.

TABLE 1. Bandgap energy of the as-prepared $\mathrm{AgCl} / \mathrm{BiYO}_{3}$

\begin{tabular}{lc}
\hline \multicolumn{1}{r}{ Compound } & Eg $(\mathrm{eV})$ \\
\hline $\mathrm{BiYO}_{3}$ & 2.62 \\
$10 \% \mathrm{AgCl} / \mathrm{BiYO}_{3}$ & 2.92 \\
$20 \% \mathrm{AgCl} / \mathrm{BiYO}_{3}$ & 3.04 \\
$30 \% \mathrm{AgCl} / \mathrm{BiYO}_{3}$ & 3.04 \\
$\mathrm{AgCl}^{*}$ & 2.93 \\
\hline
\end{tabular}

*Cao et al. 2011.

The morphology of the as-synthesized $\mathrm{BiYO}_{3}$ and $\mathrm{AgCl} / \mathrm{BiYO}_{3}$ were characterized with a SEM at $50,000 \times$ magnification (Figure 3). $\mathrm{BiYO}_{3}$ particles exhibited anomalous shape with diameters in the range of $50-60 \mathrm{~nm}$ and densely aggregated together (Figure 3(a)) while the size of $\mathrm{AgCl} / \mathrm{BiYO}_{3}$ was larger with the increasing amount of $\mathrm{AgCl}$ contents as illustrated in Figure 3(b)3(e). Since AgCl could be decomposed by the high energy electron beam, the morphology at the higher resolution was not investigated. We also used a TEM to clarify the morphology of $\mathrm{AgCl}$ on $\mathrm{BiYO}_{3}$ but failed to obtain any good results because the $\mathrm{AgCl}$ particles were not stable under electron beam. The rapid decomposition of $\mathrm{AgCl}$ under electron beam was observed as the $\mathrm{AgCl}$ particles shrunk and combined with $\mathrm{BiYO}_{3}$ particles. The EDX spectrum of $20 \% \mathrm{AgCl} / \mathrm{BiYO}_{3}$ composite with elemental mapping (Figure 3(e)) was acquired and used to confirm the existence of $\mathrm{AgCl}$ dispersed evenly on $\mathrm{BiYO}_{3}$.

The photocatalytic decompositions of RO16 by $\mathrm{BiYO}_{3}, \mathrm{AgCl} / \mathrm{BiYO}_{3}$ and $\mathrm{P} 25$ under UV and visible light illumination are shown in Figure 4. Under UV light, the photocatalytic activity of $\mathrm{AgCl} / \mathrm{BiYO}_{3}$ was almost equal to that in P25. In contrast, the photocatalytic performance of $\mathrm{AgCl} / \mathrm{BiYO}_{3}$ composite was greater than that of $\mathrm{P} 25$ when the catalyst was irradiated with visible light. This means that the $\mathrm{AgCl} / \mathrm{BiYO}_{3}$ is a better candidate visible light active material than $\mathrm{P} 25$. With this result, the mechanism of photocatalytic activity of $\mathrm{AgCl} / \mathrm{BiYO}_{3}$ under visible light irradiation was investigated and the data are displayed in Table 2. The rate constants of all samples in this work corresponded with the Langmuir-Hinshelwood (L-H) 

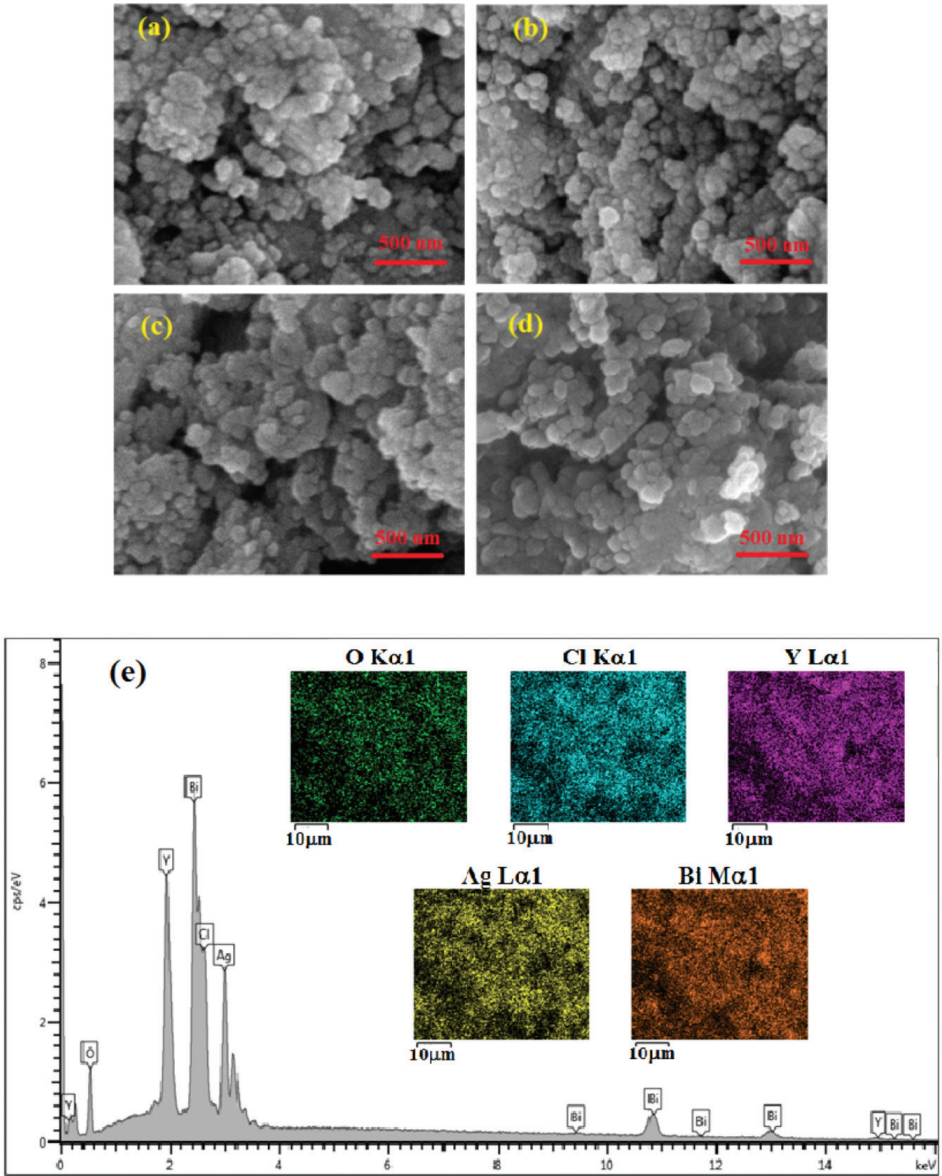

FIGURE 3. SEM images $(50,000 \mathrm{x})$ of $\mathrm{BiYO}_{3}$ (a), $10 \% \mathrm{AgCl} / \mathrm{BiYO}_{3}$ (b), $20 \% \mathrm{AgCl} / \mathrm{BiYO}_{3}$ (c), $30 \% \mathrm{AgCl} / \mathrm{BiYO}_{3}(\mathrm{~d})$, and $\mathrm{EDX}$ spectrum with elemental mapping of $20 \% \mathrm{AgCl} / \mathrm{BiYO}_{3}(\mathrm{e})$

kinetic model as given by the following equation (Dong et al. 2007; Gaya 2014; Wu et al. 2006).

$$
\mathrm{k}_{a p p} \mathrm{t}
$$

where $\mathrm{k}_{a p p}$ is the apparent pseudo-first-order rate constant $\left(\mathrm{min}^{-1}\right) ; \mathrm{C}_{0}$ is initial concentration of RO16; and $\mathrm{C}_{\mathrm{t}}$ is $\mathrm{RO} 16$ concentration at time $\mathrm{t}$. The results showed that only $10 \%$ and $7 \%$ degradations of RO16 over $\mathrm{BiYO}_{3}$ were obtained under UV and visible light irradiation for $6 \mathrm{~h}$, respectively. In contrast, the photocatalytic activities of $\mathrm{AgCl} / \mathrm{BiYO}_{3}$ with different $\mathrm{AgCl}$ contents were greatly enhanced under the same conditions. As the mole percentage of $\mathrm{AgCl}$ increased to $20 \%$, the highest photocatalytic degradation was achieved at $100 \%$ photodecomposition within $2 \mathrm{~h}$ $\left(\mathrm{k}_{a p p}=0.0214 \mathrm{~min}^{-1}\right)$. Furthermore, the photocatalytic decomposition of RO16 was slightly decreased when the molar percentage of $\mathrm{AgCl}$ reached $30 \%\left(\mathrm{k}_{a p p}=0.0211\right.$ $\mathrm{min}^{-1}$ ) indicating the optimal $\mathrm{AgCl}$ content in $\mathrm{AgCl} / \mathrm{BiYO}_{3}$ composite was $<30 \%$. Hence, $20 \%$ of $\mathrm{AgCl}$ fabricated on $\mathrm{BiYO}_{3}$ was taken as the optimal value.

Moreover, it was clearly shown that the photocatalytic activity of $\mathrm{AgCl} / \mathrm{BiYO}$ photocatlyst was much higher than that of $\mathrm{BiYO}_{3}$ itself. This photocatalytic enhancement of $\mathrm{AgCl} / \mathrm{BiYO}_{3}$ may result from the reduced recombination rate of the electron-hole pairs which, in turn, is attributable to the formation of $\mathrm{AgCl}$ and $\mathrm{BiYO}_{3}$ heterojunction in $\mathrm{AgCl} / \mathrm{BiYO}_{3}$ composite.

In the photocatalytic oxidation process, electron-hole pairs were directly produced in the photocatalyst bulk after illumination. A series of photo-induced reactive species including hole $\left(\mathrm{h}^{+}\right)$, hydroxyl radical $\left({ }^{\circ} \mathrm{OH}\right)$ and superoxide anion radical $\left({ }^{\circ} \mathrm{O}_{2}^{-}\right)$were suspected to be involved in the photocatalytic reaction. To examine the role of reactive species in photocatalytic degradation process, a series of scavengers were used to detect the relevant reactive species produced from photocatalytic process (Xu et al. 2013). Ammonium oxalate (AO), 1,4-benzoquinone (BQ) and tert-butanol (TBA) were quenchers to be used for hole $\left(\mathrm{h}^{+}\right)$, superoxide anion radical $\left({ }^{\bullet} \mathrm{O}_{2}^{-}\right)$, and hydroxyl radical $\left({ }^{\circ} \mathrm{OH}\right)$, respectively.

Figure 5 shows the photocatalytic decompositions of Ro16 with scavengers of which the experiment with low $k_{\text {app }}$ indicated the more important the role of the reactive species played in the reaction. For instance, the $k_{\text {app }}$ values for photodegradation of RO16 before and after adding TBA did not significantly change indicating the - $\mathrm{OH}$ radical was not the reactive species involved in this photocatalytic process. On the other hand, the addition of $\mathrm{AO}$ and $\mathrm{BQ}$ greatly reduced the $k_{\text {app }}$ indicating the hole 
and ${ }^{\bullet} \mathrm{O}_{2}{ }^{-}$radicals played an important role to quench the photocatalytic decomposition of RO16 under UV and visible light irradiation. when $\mathrm{AgCl}$ and $\mathrm{BiYO}_{3}$ were irradiated under UV (or visible light), the electron was excited into the conduction band and the hole was left in the valence band, as in (5). The photogenerated electron in the valence band then reacted directly with adsorbed $\mathrm{O}_{2}$ on the surface producing the ${ }^{\bullet} \mathrm{O}_{2}{ }^{-}$radical as in the following equation (6) (Gaya 2014; Lin et al. 2012):

$$
\begin{aligned}
& \mathrm{hv}+\mathrm{AgCl} \rightarrow \mathrm{h}^{+}+\mathrm{e}^{-} \\
& \mathrm{e}^{-}+\mathrm{O}_{2} \rightarrow \mathrm{O}^{-}
\end{aligned}
$$
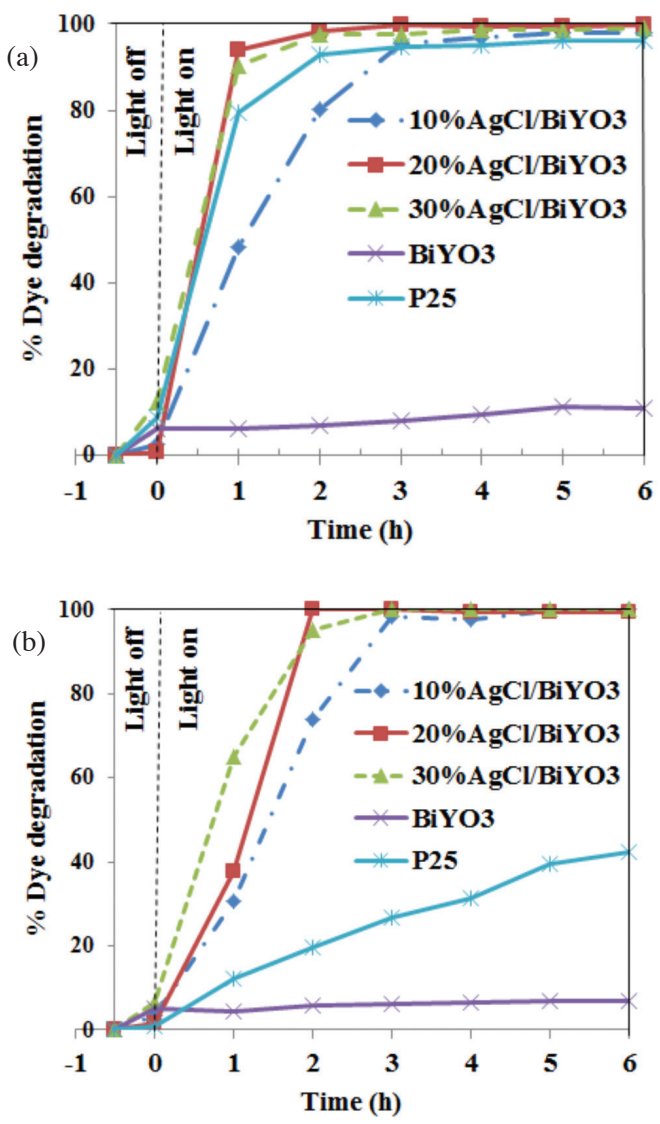

FIGURE 4. Photocatalytic degradation of RO16 over the catalysts under: (a) UV lightand (b) visible light irradiation

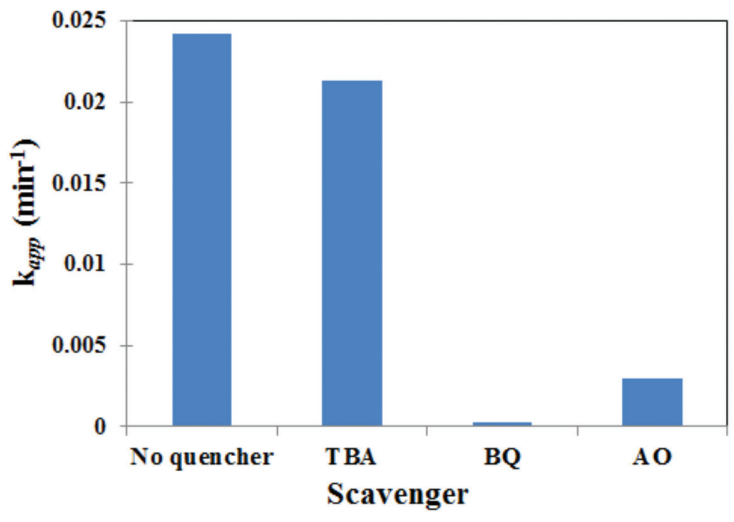

FIGURE $5 . \mathrm{k}_{a p p}$ values of $20 \% \mathrm{AgCl} / \mathrm{BiYO}_{3}$ with various quenchers under visible light irradiation

Therefore, both hole and ${ }^{\bullet} \mathrm{O}_{2}^{-}$species were the dominating reactive species that finally degraded RO16 in this work. The possible mechanism for the RO16 decomposition over $\mathrm{AgCl} / \mathrm{BiYO}_{3}$ composite could be proposed in Figure 6 . The conduction band $(0.11 \mathrm{eV})$ and valence band (3.04 eV) of $\mathrm{AgCl}$ lie below those of $\mathrm{BiYO}_{3}\left(E_{\mathrm{VB}}=2.58 \mathrm{eV}, E_{\mathrm{CB}}=-0.04 \mathrm{eV}\right)$, respectively. After irradiation, the photogenerated electrons migrated from the conduction band of $\mathrm{BiYO}_{3}$ to that of $\mathrm{AgCl}$. Meanwhile, the photogenerated holes moved conversely from valence band of $\mathrm{AgCl}$ to the lower valence band of $\mathrm{BiYO}_{3}$. Through this process, it effectively reduced the recombination of the electron-hole pairs, which is believed to be the key factor to improve the photocatalytic performance of $\mathrm{AgCl} /$ $\mathrm{BiYO}_{3}$ (Lin et al. 2012). Furthermore, the accumulated electrons on the $\mathrm{AgCl}$ immediately reacted with the adsorbed $\mathrm{O}_{2}$ on the surface of composite to produce reactive ${ }^{\bullet} \mathrm{O}_{2}^{-}$. It was also noted that the holes, which accumulated on the $\mathrm{BiYO}_{3}$, could react directly with Ro16. These two above mechanisms finally led to the degradation of Ro16. However, in the case of $\mathrm{BiYO}_{3}$, it could be stimulated to produce electron-hole pairs by both UV and visible light and decomposed RO16 to $\mathrm{ca}$. $20 \%$ within 6 h of irradiation, as shown in Figure 4, but the bandgap energy of $\mathrm{BiYO}_{3}(2.62 \mathrm{eV})$ was very narrow that the recombination of the electron-hole pairs became significant. Therefore, based on the above discussion, it can be proved that the decomposition of RO16 could be attributed to the reaction with hole and ${ }^{\circ} \mathrm{O}_{2}^{-}$species during the photocatalytic reaction.

TABLE 2. The photodegradation efficiencies and $\mathrm{k}_{a p p}$ values of RO16 from various photocatalysts under visible light irradiation for $6 \mathrm{~h}$

\begin{tabular}{lccc}
\hline Photocatalyst & \% dye degradation & $\mathrm{k}_{a p p}\left(\mathrm{~min}^{-1}\right)$ & $\mathrm{R}^{2}$ \\
\hline $\mathrm{BiYO}_{3}$ & 19 & 0.0006 & 0.8247 \\
$10 \% \mathrm{AgCl} / \mathrm{BiYO}_{3}$ & 100 & 0.0190 & 0.9524 \\
$20 \% \mathrm{AgCl} / \mathrm{BiYO}_{3}$ & 100 & 0.0214 & 0.9410 \\
$30 \% \mathrm{AgCl} / \mathrm{BiYO}_{3}$ & 100 & 0.0211 & 0.9564 \\
\hline
\end{tabular}




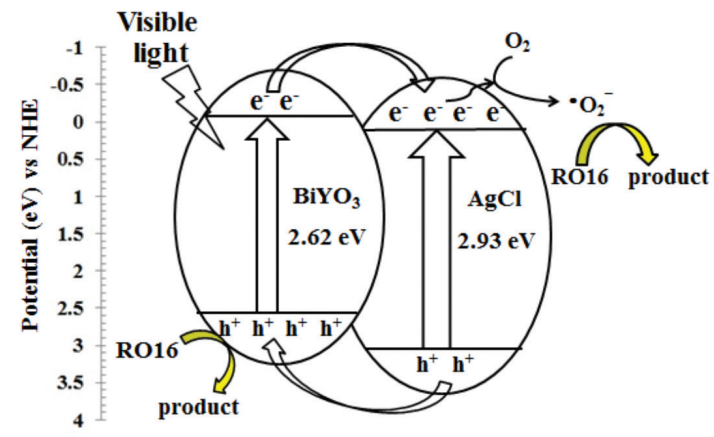

FIGURE 6. Schematic diagram of electron-hole separation process of $\mathrm{AgCl} / \mathrm{BiYO}_{3}$ photocatalyst under visible light

\section{CONCLUSION}

In this work, $\mathrm{AgCl} / \mathrm{BiYO}_{3}$ composite was successfully synthesized. Both $\mathrm{BiYO}_{3}$ and $\mathrm{AgCl}$ show good visible-light absorption, but $\mathrm{BiYO}_{3}$ itself displays low photocatalytic activity. The fabrication of $\mathrm{AgCl}$ onto $\mathrm{BiYO}_{3}$ enhanced the photodegradation efficiency of RO16 to $100 \%$ within 1 and $2 \mathrm{~h}$ under $\mathrm{UV}$ and visible light, respectively, especially for $20 \% \mathrm{AgCl} / \mathrm{BiYO}_{3}$ with $\mathrm{k}_{a p p}$ value of $0.0214 \mathrm{~min}^{-1}$. The enhancement of photocatalytic activity of $\mathrm{AgCl} / \mathrm{BiYO}_{3}$ can be attributed to the effective electron-holepairs separation at $\mathrm{AgCl} / \mathrm{BiYO}_{3}$ heterojunction interfaces. The evaluation of photocatalytic mechanism illustrated that the hole and ${ }^{\bullet} \mathrm{O}_{2}{ }^{-}$species were the dominant reactive species for photodecomposition of RO16 under visible light irradiation. Results from this work show that the $\mathrm{AgCl} / \mathrm{BiYO}_{3}$ is a capable supported- $\mathrm{AgCl}$ composite in photocatalytic degradation of RO16 under both UV and visible light illumination.

\section{ACKNOWLEDGMENTS}

This work was supported by the government budget of Prince of Songkla University (No. SCI570504S) and the Department of Chemistry, Faculty of Science, Prince of Songkla University.

\section{REFERENCES}

Cao, J., Xu, B., Luo, B., Lin, H. \& Chen, S. 2011. Preparation, characterization and visible-light photocatalytic activity of $\mathrm{AgI} / \mathrm{AgCl} / \mathrm{TiO}_{2}$. Applied Surface Science 257: 7083-7089.

Cai, P., Zhou, S.M., Ma, D.K., Liu, S.N., Chen, W. \& Huang, S.M. 2015. $\mathrm{Fe}_{2} \mathrm{O}_{3}$-modified porous $\mathrm{BiVO}_{4}$ nanoplates with enhanced photocatalytic activity. Nano-Micro Letter 7: 183-193.

Chen, C., Ma, W. \& Zhao, J. 2010. Semiconductor-mediated photodegradation of pollutants under visible-light irradiation. Chemical Society Reviews 39: 4206-4219.

Cheng, F.H., Huang, B.B., Dai, Y., Qi, Y.X. \& Zhang, Y.X. 2010. One-step synthesis of the nanostructured $\mathrm{AgCl} / \mathrm{BiOI}$ composites with highly enhanced visible-light photocatalytic performance. Langmuir 26: 6618-6624.

Cheng, Y., Wang, H., Zhu, Y., Liao, F., Li, Z. \& Li, J 2015. One-step hydrothermal synthesis of $\mathrm{BiVO}_{4}-\mathrm{Bi}_{2} \mathrm{O}_{3} \mathrm{p}$-n heterojunction composites and their enhanced photocatalysis properties. Journal of Material Science: Material Electron 26: 1268-1274.

Chong, M.N., Jin, B., Chow, C.W.K. \& Saint, C. 2010. Recent developments in photocatalytic water treatment technology: A review. Water Research 44: 2997-3027.

Dong, X., Ding, W., Zhang, X. \& Liang, X. 2007. Mechanism and kinetics model for degradation of synthetic dyes by UV-Vis $/ \mathrm{H}_{2} \mathrm{O}_{2}$ /ferrioxallate complexes. Dye and Pigments 74: $470-476$.

Gaya, I.U. 2014. Heterogeneous Photocatalysis using Inorganic Semiconductor Solids. Dordrecht: Springer Netherlands. pp. 23-26 and 43-71.

Hu, X., Li, G. \& Yu, J.C. 2010. Design, fabrication, and modification of nanostructured semiconductor materials for environmental and energy applications. Langmuir 26: 3031-3039.

Lin, H.L., Cao, J., Luo, B.D., Xu, B.Y. \& Chen, S.F. 2012. Visiblelight photocatalytic activity and mechanism of novel AgBr/ $\mathrm{BiOBr}$ prepared by deposition-precipitation. Chinese Science Bulletin 57: 2901-2907.

Pan, L., Hu, B., Zhu, X., Chen, X., Shang, J., Tan, H., Xue, W., Zhu, Y., Liu, G. \& Li, W.R. 2013. Role of oxadiazole moiety in different $\mathrm{D}$-A polyazothines and related resistive switching properties. Journal of Material Chemistry C 1: 4556-4564.

Qin, Z., Liu, Z., Liu, Y. \& Yang, K. 2009. Synthesis of $\mathrm{BiYO}_{3}$ for degradation of organic compounds under visible-light irradiation. Catalysis Communication 10: 1604-1608.

Qin, Z., Tian, H., Su, T., Ji, H. \& Guo, Z. 2016. Soft template inducted hydrothermal $\mathrm{BiYO}_{3}$ catalysts for enhanced formic acid formation from the photocatalytic reduction of carbon dioxide. RSC Advances 6: 52665-62673.

Sood, S., Umar, A., Mehta, S.K. \& Kansal, S.K. 2015. $\alpha-\mathrm{Bi}_{2} \mathrm{O}_{3}$ nanorod: An efficient sunlight active photocatalyst for degradation of Rhodamine B and 2,4,6-trichlorophenol. Ceramics International 41: 3355-3364.

Tariq, M.A., Faisal, M., Muneer, M. \& Bahnemann, D. 2007. Photochemical reactions of a few selected pesticide derivatives and other priority organic pollutants in aqueous suspensions of titanium dioxide. Journal of Molecular Catalysis A: Chemical 265: 231-236.

Wang, D.W., Huang, Q.F., Lin, P.X. \& Yang, H.J. 2008. Visiblelight-responsive photocatalyst $x \mathrm{BiOBr}-(1-x) \mathrm{BiOI}$. Catalysis Communication 9: 8-12.

Wu, C., Chang, H. \& Chen, J. 2006. Basic dye decomposition kinetics in a photocatalytic slurry reactor. Journal of Hazardous Materials B 137: 336-343.

Wu, M., Xu, D., Lou, B., Shen, H., Wang, C. \& Shi, W. 2015. Synthesis of $\mathrm{BiYO}_{3}$ nanorods with visible-light photocatalytic activity for the degradation of tetracycline. Materials Letters 161: 45-48.

Xu, C.Y., Hu, S.P., Zhang, B.Y., Pei, Y. \& Zhen, L. 2014. Solvothermal synthesis of $\mathrm{Bi}_{2} \mathrm{O}_{2} \mathrm{CO}_{3}$ nanoplates for efficient photodegradation of $\mathrm{RhB}$ and phenol under simulated solar light irradiation. Bulletin of Korean Chemical Society 35: 2935-2940.

Xu, H., Yan, J., Xu, Y., Song, Y., Li, H., Xia, J., Huang, C. \& Wan, H. 2013. Novel visible-light-driven $\mathrm{AgX} /$ graphite-like $\mathrm{C}_{3} \mathrm{~N}_{4}$ $(\mathrm{X}=\mathrm{Br}, \mathrm{I})$ hybrid materials with synergistic photocatalytic activity. Applied Catalysis B: Environmental 129: 182-193.

Xu, L., Lu, H., Wei, B., Zhang, M., Gao, H. \& Sun, W. 2014. Enhanced photosensitization process induced by the p-n junction of $\mathrm{Bi}_{2} \mathrm{O}_{2} \mathrm{CO}_{3} / \mathrm{BiOCl}$ heterojunctions on the 
degradation of rhodamine B. Applied Surface Science 303: 360-366.

Xue, B., Sun, T., Wu, J., Mao, F. \& Yang, W. 2015. AgCl/TiO nanocomposites: Ultrasound-assisted preparation, visiblelight induced photocatalytic degradation of methyl orange and antibacterial activity. Ultrasonics Sonochemistry 22: 1-6.

Yan, J., Wang, C., Xu, H., Xu, Y., She, X., Chen, J. \& Song, Y. 2013. AgI/ $/ \mathrm{Ag}_{3} \mathrm{PO}_{4}$ heterojunction composites with enhanced photocatalytic activity under visible light irradiation. Applied Surface Science 287: 178-186.

Zhou, B., Zhao, X., Liu, H., Qu, J. \& Huang, C.P. 2011. Synthesis of visible-light sensitive $\mathrm{M}-\mathrm{BiVO}_{4}(\mathrm{M}=\mathrm{Ag}, \mathrm{Co}$, and $\mathrm{Ni})$ for the photocatalytic degradation of organic pollutants. Separation and Purification Technology 77: 275-282.
Department of Chemistry and Center of Excellence for Innovation in Chemistry

Faculty of Science

Prince of Songkla University

Kanjanawanich Rd., Kohong

Hatyai, Songkhla, 90110

Thailand

*Corresponding author; email: uraiwan.s@psu.ac.th

Received: 31 August 2016

Accepted: 17 January 2017 